\title{
Causes and Effects of Design Change in Building Construction Projects in Three Selected Southern Ethiopia Zones.
}

\author{
Matusala Bassa, Ashenafi Reta, Ashebir Alyew, Mamo Tora \\ Lecturer, Civil Engineering Department, Wolaita Sodo University, Ethiopia
}

\begin{abstract}
The main parties involved in Construction industry consists of Owner/Employer/client, Engineer/consultant, contractor, bank, insurance and government body. Among these one or more of the parties initiate the design change due to internal and external factors which lead to both time and cost overrun in construction project. The objective of this study is investigating the causes and effects of design change in building construction projects. The research methodology engaged a questionnaire survey containing of fifty-one (51) questions about the cause and effect of design changes during the building construction, which was distributed to the project managers, client and the Engineers. The questionnaire responses were analyzed based on Relative importance index. The results indicated that lack of design review during design

process, errors and omission in design, plans change by client, incomplete contract documents, differing site conditions, lack of experience for design evaluation during design period and impediment in prompt decision making process were the most causes of design change. The results also showed that completion schedule delay, increase in project cost, wastage of materials during rework, productivity degradation and working extra hours (overtime) to meet deadlines of the project were the most impacts of design change
\end{abstract}

Key words: - design change, causes, impacts, construction projects

\section{INTRODUCTION}

The nature of construction industry is complex and uncertain because of different firms are involved from inception stage to commissioning stage. Design is a process of creating the description of a new facility, usually represented by detailed plans and specifications; construction planning is a process of identifying activities and resources required to make the design a physical reality [1] In an integrated system, the planning for both design and construction can proceed almost simultaneously, examining various alternatives which are desirable from both viewpoints and thus eliminating the necessity of extensive revisions under the guise of value engineering. Furthermore, the review of designs with regard to their constructability can be carried out as the project progresses from planning to design [1]. According to Ethiopia Construction industry the lion share of design preparation part goes to consultant firms. Design change is mainly common problem and it affects whole project construction performance according to the following literature reviews. The design change initiated by one the following parties owner, consultant, consultant construction management, politics and economics, natural environment, contractors, third party and advances in technology [2]. Design changes requested by owners include additions, deletions and/or modifications to the original scope of the work [3]. According to first Ethiopia condition of contract (BATCODA) the Consultant shall prepare as built final drawings and records of the works to give information of both visible and concealed work to enable the Investor carry out future changes in design or modification of works with ease and without measurement and investigation. Such records shall include all changed date and information up to the beginning of the Maintenance Period. [The as built drawings and records shall be reviewed by the Engineer and resubmitted by incorporating any comments.]

\section{STAGE OF CONSTRUCTION IN BUILDING PROJECTS}

Stages of building construction projects include Inception and feasibility, planning and design stage, tendering stage, bid evaluation/ evaluation of tenders, award of contract, construction stage and commissioning and acceptance.

\section{FACTORS AFFECTING THE DESIGN CHANGE IN BUILDING PROJECT DURING CONSTRUCTION}

Changes of design in construction can be caused by various sources at different stages of the project, however in this research the focus is during construction stage. The cause of change may originate from external or internal issues that may occur during the development phases of project i.e. from basic design to construction [4]. The internal factors are the client related, contractor related and consultant related factors. The external factors are Environmental, third parties and Political and economic factors. The research conducted in India identified from top ten factors in design development are structural design parameters, soil investigations, design quality control, topographic survey, and architectural design parameters, preparation of design intent/ideology, Site analysis from design and context perspective, local byelaws/regulations multi-disciplinary coordination/review meetings and Lifespan/design period consideration [5]. The research conducted in India identified 30 significant factors in the design development process that could be used as a checklist to ensure that design processes 
are complete and considers important sub-processes such as standardization, value engineering, and reviews [5]. But the factors depend according to the research area. The research conducted in Tanzania investigated that the client's factors and design consultant factors have more influence in change of design during construction stage for internal factors and the environmental factors found to have large influence to change of design followed by the third parties factors for external factors [6]. According to [7] the most five common causes of change orders can be identified as: change of plans by owner, change of project scope by owner (additionalenhancement), problems on site, errors and omission in design (main element), poor design and poor working drawing details (secondary element). Another research study found that the owner was the main factor that caused design changes in a construction project and other factors were respectively design consultants, construction management consultants, political and economic matters, the natural environment, contractors, third parties and the advance of technologies [2]. The critical appraisal of literature relating to causes of design changes and the resultant rework that cause delay and disruption which result in time delays and cost overruns in building construction projects has been presented. This study establishes that literature linking design changes and rework in construction projects is limited but found out that design changes is the significant factor for time delays and cost overruns [8]. According to literature review [9] the major ranked causes of design change as change of plan by owner, Substitution of materials, change in design by consultant; Errors and omissions in design, the scope of work for a contractor is not well defined, Conflict between contract documents, differing site conditions, change of plan by client; The lack of coordination between contractor and consultant; The contractor's financial difficulties, owner's financial problems, Workmanship or material is not meeting the specification, Contractor's desire to improve his financial situation; The required labor skills are not available, The required equipment and tools are not available, New government regulations, and Weather conditions. A study conducted in Oman investigated and listed causes of change in public construction project as Owner instructs additional work; Owner instructs modification to design; Nonavailability of construction manuals and procedures for project construction in Oman; Non-availability of engineering licensing for engineers in Oman to maintain the quality of consultancy services; Poor communication between relevant governmental units and the owner; Nonavailability of overall project planning; Unrealistic design periods; Unrealistic construction schedule; Owner fails to make decisions or review documents at the right time; Low consultancy fee or less experienced designers; Nonavailability of records of similar projects in Oman; Failure by the consultant to provide adequate and clear information in the tender documents; Natural growth of the project was not anticipated at the design stage; Owner's needs during the design stage are unclear or not well-defined; The contractor uses the gray areas in general conditions and request variations to the contract; Design errors; The design and construction criteria are outdated and do not suit the present construction technology; The contractor misses variations instructions; Non-availability of qualified engineers from the owner side; Consultant not familiar with the regulations and construction permits in Oman; Unilateral decisions made by the owner without proper considerations to the contract; Consultant's supervisors do not have collective experience about construction projects in Oman; Failure by the consultant to perform design and supervision effectively; and Poor project management by contractor [10]. The study in Pakistan indicated top three discrepancies between design and construction as provision of incomplete data to designers, lack of interest by approving authorities to carefully check the design, and ownerproposed changes due to financial problems [11].

Generally Causes of design change as described by different authors summarized as client related (change requirement, new technology, value Engineering, unclear brief), contractor related (request to use available material, alternative construction methodology), site related (location, underground condition) and design related (design error, inconsistent site condition, design omission, unpredictable circumstance during construction, modification to design).

\section{EFFECT OF DESIGN CHANGE IN BUILDING PROJECT DURING CONSTRUCTION}

The construction industry performance measured by three major parameters cost, time and quality. However, the design change affects the whole process of project and the effects listed below are mostly occurred in Ethiopia Construction industry. Cost overrun, time overrun, quality problem, increases overhead expenses, wastage of materials due to rework, Productivity degradation due to equipment and material, claim and disputes occur between client and contractor. The most common effects for those projects that change of design took place during construction stage were delay of the projects, increasing of cost of the project (cost overrun), abandoning of the project, wastage of materials and conflicts between the parties [6]. The study conducted in Nigeria found that design change due to poor working drawing (omission on structural drawing) leads to variation [12]. Design changes frequently impact project cost and time and have the potential to increase the possibility of conflicts between owners and contractors. Project time and cost change impact can become severe if owners do not consider the fact that a change in one part of the project may cause a series of changes in other parts of the project, which is known as the "change ripple effect." Therefore, for the wellorganized delivery of construction projects, it is essential to have an efficient design change management system [3]. The critical appraisal of literature relating to causes of design changes and the resultant rework that cause delay and disruption which result in time delays and cost overruns in building construction projects has been presented [8].

The effects of design change from different scholars can be summarized as additional payment for contractors, rework, demolition, completion schedule delay, increased overhead expenses and increase the possibility of conflicts between owners and contractors 


\section{RESEARCH OBJECTIVES}

The objective of this study is to identify Causes and effects of design change in building construction projects of three selected southern Ethiopian zones.

\section{METHODOLOGY}

In order to Determine and analyse the causes and effects of design change in public construction projects of Wolaita Sodo, Arba Minch and Hawassa cities, a wide range of personnel involved in construction projects of southern Ethiopia cities were targeted. Personnel were selected from project managers, consultants, contractors, client's representatives and construction managers. A questionnaire was carefully designed from previous preliminary investigations conducted in construction projects. It was organised in the form of a priority scaling (1=very low, 2=low, 3=medium, 4=high, and 5=very high). The questionnaire was distributed to purposively selected sample of clients, consultants and contractors. The sample selected for each of the three groups is described below as:

Clients encompassing the government agency responsible for the projects, private organisations, and individual owners.

$>$ Consulting groups who designed the projects of southern Ethiopia.
Contractors who are executing in the construction projects of southern Ethiopia.

Respondents were from public and private agencies that sponsor construction projects, and the contracting and consulting organisations that work for them.

\section{Data Analysis}

The Relative Important Index (RII) method was adopted for similar studies to determine the relative importance of various factors [13]. This method is applied to this study to identify the Relative importance of various causes and effects of design change based on responses from contractors, owners and consultants.

$$
\mathrm{RII}=\left(\frac{\sum(W)}{A * N}\right)
$$

where: $\mathrm{W}=$ the weight given to each factor by the respondents

$$
\begin{aligned}
& A=\text { the highest weight }=5 \\
& N=\text { the total number of respondents. }
\end{aligned}
$$

The RII is used to rank the groups of questionnaire by calculating the average of relative importance index of all factors in the group.

\section{RESULT ANALYSIS AND DISCUSSION}

Table 1: RII and Rank of top 5 causes of design change in construction projects

\begin{tabular}{|l|l|l|l|}
\hline No. & \multicolumn{1}{|c|}{ Table 1: RII and Rank of top 5 causes of design change in construction projects } & RII & Rank \\
\hline 1 & Lack of design review during design process & 0.79 & 1 \\
\hline 2 & Errors and omission in design & 0.77 & 2 \\
\hline 3 & Change of plan by clients & 0.65 & 3 \\
\hline 4 & Incomplete contract document & 0.58 & 4 \\
\hline 5 & Differing site condition & 0.56 & 5 \\
\hline
\end{tabular}

Top 5 causes of design change in construction project

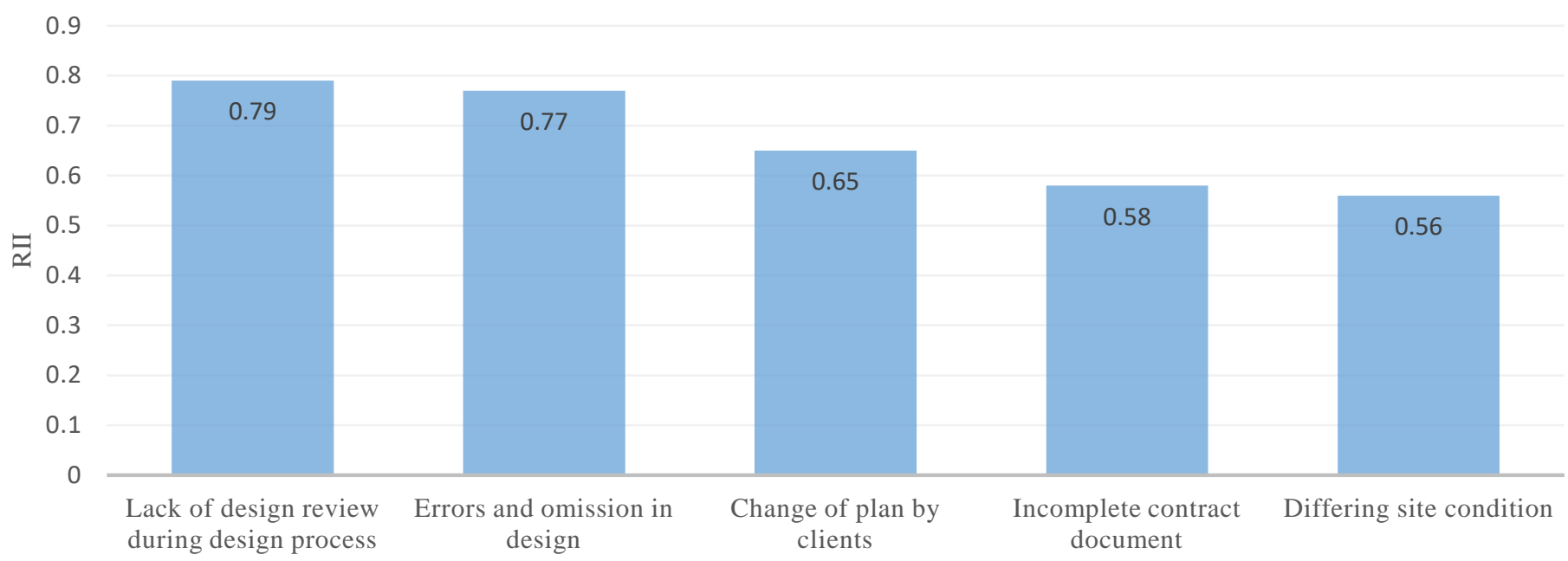

CAUSES OF DESIGN CHANGE

Figure1: Top 5 causes of design change in construction projects 
From the table 1 and figure 1 above lack of design review during design process with $\mathrm{RII}=79 \%$ takes the first place as a cause of design change at the study area. Design review is the process of evaluating the design against its requirement to identify issues before proceeding the work. It should be a culture \& mandatory for every design. Lack of design review results change of design after the project is started. Errors and omissions in design with $\mathrm{RII}=77 \%$ is the second cause of design change in construction projects as respondent's perspective. Design error is lack of instruction in the specification and or plan and design omission is missing what is compulsory to complete the design or comply with the design code. Once again, this result change in design and costs the owner for its replacement. The way to reduce change of design caused by errors and omissions is using design templates. Change of plan by clients with RII $=65 \%$ is the third cause of design change. This is due to insufficient time allocation for briefing, absence of end user's involvement, late exposition of requirements, and inexperience of client in construction [14]. The fourth and fifth cause of design change is incomplete contract document with $\mathrm{RII}=58 \%$ and Differing site condition with $\mathrm{RII}=56 \%$ respectively.

Table 2: RII and Rank of top 5 Impacts of design change in construction projects

\begin{tabular}{|l|l|l|l|}
\hline No. & \multicolumn{1}{|c|}{ Impacts } & RII & Rank \\
\hline 1 & Completion schedule delay & 0.91 & 1 \\
\hline 2 & Increase in project cost & 0.88 & 2 \\
\hline 3 & Wastage of materials during rework & 0.81 & 3 \\
\hline 4 & Productivity degradation & 0.75 & 4 \\
\hline 5 & working extra hours (overtime) to meet deadlines of the project & 0.68 & 5 \\
\hline
\end{tabular}

Top 5 impacts of design change in construction projects

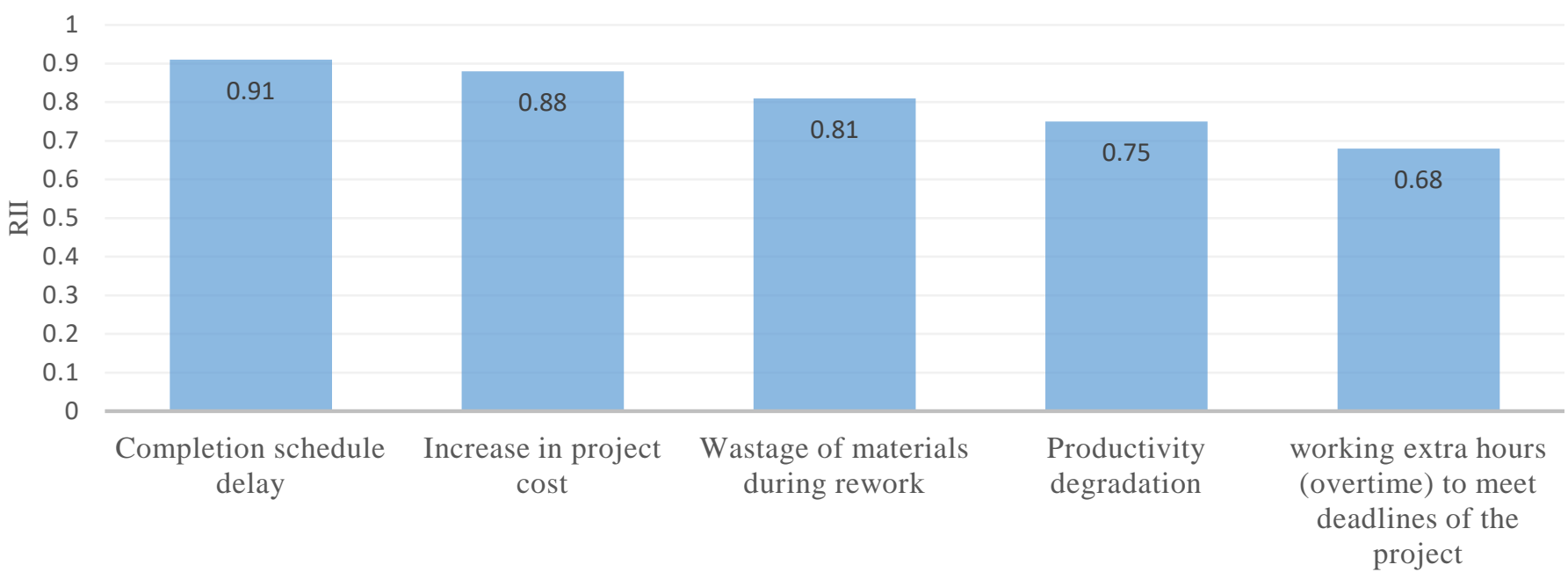

IMPACTS OF DESIGN CHANGE

Figure 2: Top 5 impacts of design change in construction projects

From the table 2 and figure 2 above completion schedule delay with $\mathrm{RII}=91 \%$ is the primary effect of design change as respondents' perspective. Construction delay is not only caused by design changes but also Untimely payment \& financial difficulties, Variations and Change orders, late site handover, Mistakes in contract documents, Lack of appropriate supervision, Construction mistakes or poor workmanship, Late issuance of instructions \& poor communications among parties, Material procurement problem, Equipment management problems, and Inclement weather \& Unforeseen site conditions are the causative factors of delay [15]. Increase in project cost with $\mathrm{RII}=88 \%$ is the second impact of design change. Design change at the stage of construction requires replacement of design (re design) and or rework. Once again this costs the client which results increase in project cost as a whole. Wastage of materials during rework with $\mathrm{RII}=81 \%$ takes the third place as effect of design change. Design change at the construction stage may require demolition and rework of already constructed part. This results wastage of construction material. Productivity degradation with $\mathrm{RII}=75 \%$ and working extra hours (overtime) to meet deadlines of the project with RII $=68 \%$ is the fourth and fifth impact of design change respectively.

\section{CONCLUSION}

The finding from the study and literatures revels that the causes of design change in the study area includes (1) Lack of design review during design process, (2)Errors and omission in design, (3)Change of plan by clients, (4)Incomplete contract document and (4)Differing site condition. Again the finding from the study indicated the major impacts of design change as (1) Completion schedule 
delay, (2) Increase in project cost, (3)Wastage of materials during rework, (4) Productivity degradation and (5) working extra hours (overtime) to meet deadlines of the project

\section{REFERENCES}

[1] Chris Hendrickson, Project Management for Construction, S. Edition, Ed., 2003.

[2] A. A. Gde Agung Yanaa, Rusdhi H. A and M. Agung Wibowo, "Analysis of factors affecting design changes in construction project with Partial Least Square (PLS)," The 5th International Conference of Euro Asia Civil Engineering Forum (EACEF-5), p. 40 - 45, 2015.

[3] Valeh Moayeri , Design Change Management in Construction Projects Using Building Information Modeling (BIM), Canada: Concordia University, 2017.

[4] Gharaee M., "Change Management and Change Process Model for the Iranian Construction Industry," A Journal of Management, vol. 2, no. 2, pp. 85- 9, 2012.

[5] Devanshu Pandit,, Sanjay M. Yada and Sardar Vallabhbhai, "FACTORS AFFECTING EFFICIENT CONSTRUCTION PROJECT DESIGN DEVELOPMENT: A PERSPECTIVE FROM INDIA," INTERNATIONAL JOURNAL OF CONSTRUCTION SUPPLY CHAIN MANAGEMENT , vol. 5, no. 2, 2015.

[6] Iliyas J. Suleiman and Valentine G. M. Luvara, "Factors Influencing Change of Design of Building Projects during Construction Stage in Dar-es- Salaam Tanzania," International Journal of Construction Engineering and Management, vol. 4, pp. 93-101 , 2016.

[7] Alia Alaryan, Emadelbeltag, Ashraf Elshahat and Mahmoud Dawood, "Causes and Effects of Change Orders on Construction Projects in Kuwait," Journal of Engineering Research and Applications , vol. 4, no. 2, pp. 01-08, July 2014.

[8] J. B. H. Yap, H. Abdul-Rahman and C. Wang, "A Conceptual Framework for Managing Design Changes in Building Construction," MATEC Web of Conferences, vol. 66, no. 0021, 2016.

[9] Mohammad, N., Ani, C, Rakmat, R.A.O.K and Yusof, M.A, "Investigation on the Causes of Variation Orders in the Construction of Building Project - A Study inthe State of Selangor, Malaysia," Journal of Building Performance, vol. 1, no. 1, pp. 73-82, 2010.

[10] Alnuaimi, A., , Taha, R., , Al Mohsin, M., and Al-Hart, "causes, effectsBenefits, and Remedies of Change Orders on Public Construction Projects in oman," Journal of Construction of Engineering Management. , pp. 615-622. , may 2010.

[11] Rafiq Muhammad Choudhry, Hamza Farooq Gabriel, Mustafa Kamal Khan and Salman Azhar, "Causes of Discrepancies between Design and Construction in the pakistan construction industry," Journal of Construction in Developing Countries, , vol. 22, no. 2, pp. 1-18, 2017.

[12] Oluwas eun Sunday, Dos umu and Clinton O, Aigbavboa, "Impact of design errors on variation cost of selected building project in Nigeria," Primosten, Croatia, 2017.

[13] Sambasivan, M and Soon, Y. W, "Causes and effects of delays in Malaysian construction industry," international Journal of Project Management, vol. 25, no. 5, pp. 517-526, 2007.

[14] Ashenafi Reta, Matusala Bassa and Ashebir Alyew, "Evaluation of causes of claims on construction projects of Southern Nation Nationality and People Region, Ethiopia," International Journal of Engineering Research \& Technology (IJERT), vol. 8, no. 12, pp. 154160, 2019.

[15] Ashebir Alyew, Ashenafi Reta and Matusala Bassa, "VALUATION OF CONSTRUCTION DELAYS, CAUSATIVE FACTORS AND EFFECTS IN SOUTHERN ETHIOPIA CONSTRUCTIONPROJECTS," Journal of Emerging Technologies and Innovative Research (JETIR), vol. 6, no. 6, pp. 542-546, 2019. 